\title{
Examination of the Relationship between Derivative Financial Instruments and the Economic Development of Lithuania
}

\author{
Kristina Garskaite-Milvydiene and Raimonda Martinkute-Kauliene
}

ABSTRACT

\begin{abstract}
Derivative financial instruments play a major role in financial markets. However, there are rather contradictory views regarding this issue. Their impact on the financial markets, their stability and the economy have not been thoroughly examined. The aim of this paper is to analyse derivatives and the economic situation in the country and to investigate the relationship between the derivatives and the macroeconomic factors which have the greatest impact on the volume of the derivatives. The paper analyses derivatives statistics and macroeconomic indicators in Lithuania. As a result, the relationship between the derivatives and the country's macroeconomic indicators is examined by identifying the most significant factors, as the structure and volume of derivatives in different markets may be determined by different macroeconomic factors. The performed analysis and estimation have shown that foreign direct investment has the largest impact on the derivatives, their volume and structure, and average earnings have the least impact.
\end{abstract}

KEY WORDS: $\quad$ Derivative financial instruments (derivatives), foreign exchange transactions and interest rate derivative contracts, GDP, inflation, unemployment rate.

JEL Classification: F23, G01, G10, G34.

Faculty of Business Management, Vilnius Gediminas Technical University, Lithuania

\section{Introduction}

Under global economy conditions, the market is affected by a variety of factors: economic, social, political, technological, and others. As processes are progressing rapidly, more and more innovations and technologies are emerging, opening a wealth of opportunities and providing communications with the whole world. The financial market is becoming more accessible and greater investment opportunities are emerging (European Securities and Markets Authority [ESMA], 2018; European Central Bank [ECB], 2019). The popularity of investing is influenced by a more easily accessible investment environment and the increasing choice of financial instruments available for investment (Lenee \& Oki, 2017; Jermann \& Yue, 2018). Investing as a process is

Correspondence concerning this article should be addressed to: Kristina Garskaite-Milvydiene, Faculty of Business Management, Vilnius Gediminas Technical University, Lithuania.

E-mail: kristina.garskaite-milvydiene@vgtu.lt aimed at preserving and increasing the value of cash (Faure, 2015; Antelo \& Bru, 2018). All investments are exposed to certain risks, which are to be avoided to prevent losses (Martinkutè-Kaulienè, 2014). The derivatives market is particularly highly developed (Brigham \& Davies, 2015; Klingeberg et al., 2018).

The financial crisis that hit the US in 2007 gained tremendous momentum in 2008 not only in the US, but spread across the globe directly affecting Europe and indirectly spreading to rapidly emerging markets (Kazi et al., 2013; Lel, 2014; Mayordomo et al., 2014). The crisis highlighted the risks of derivatives and their manifestations, their advantages, and disadvantages (Obstfeld \& Rogoff, 2009).

Thus, following the devastating experience and after making improvements in terms of the nature and regulation of derivatives, the wider use of derivatives providing a hedge against fluctuations in interest rates, exchange rates, raw material prices, and other risks began to be promoted in risk man- 
agement (Shibli, 2012; Martinkutè-Kaulienė, 2014; Kosowski \& Neftci, 2015). The derivatives are usually divided into different types that possess certain characteristics, hence choosing the appropriate type of a transaction is important when seeking to conclude a transaction that meets all expectations and helps avoid risks (Blažek \& Netrdova, 2012; Araujo \& Leao, 2016).

Derivative financial instruments are used not only for risk management but also for speculative purposes (Carneiro et al., 2015). The implementation of and the benefits obtained from transactions often also depend on the economic situation in a country (Burns \& Tobin, 2016), as it affects prices, in this case, the underlying assets of a transaction, which can comprise both securities, exchange rates and raw materials, ordinary commodities, and so on. (Bejol \& Livingstone, 2018; Butt et al., 2018). Therefore, it is important to analyse what macroeconomic factors determine the volume of certain transactions so as to take, based on forecasts, the most appropriate decision in choosing the right derivative. To determine the relationship between the volume of derivatives transactions and macroeconomic factors, correlation/regression analysis and multiple regression analysis will be used for the relationship between the derivatives and the country's economic development and the strength of such a relationship to be determined.

The aim of the study is to analyse derivatives and the economic situation in the country and to examine the relationship between these factors, to identify those which have the largest impact on the derivatives and their impact on the country's economic development. To achieve this aim, statistics on the derivatives and Lithuania's macroeconomic indicators were analysed; the relationship between the derivatives and the country's macroeconomic indicators was determined.

The aim of the paper was achieved by summarising and systematising the views of other authors, analysing statistical data, using correlation/regression analysis and multiple regression analysis.

The first part of the paper analyses statistical data on derivative financial instruments, namely, their dynamics and structure. The second part examines statistical data on Lithuania's macroeconomic indi- cators (gross domestic product, foreign direct investment, inflation, unemployment rate, average annual earnings) and their dynamics. The third part investigates the relationship between the volume of derivatives transactions and the macroeconomic indicators and determines the strength of this relationship, identifies the indicators which mainly influence the volume of certain derivatives transactions.

\section{Analysis of Statistics on Derivative Financial Instruments}

Globalisation and financial integration lead to a rapid spread of derivatives around the world (David, 2009; Bae et al., 2017; Inekwe, 2018). Particularly, as regards emerging markets, it is a matter of vital importance to properly select and use these instruments and to recognise the risks associated with them (Bartram et al., 2009; Foster \& Magdoff, 2009). Typically, derivatives improve risk spread within a financial system. The derivatives make risk management more effective and flexible, especially in banks, also they contribute to the more effective distribution of individual risks and reduce the related overall risk in the economy (Bezzina \& Grima, 2012; Bingham \& Kiesel, 2013; Bae et al., 2017; Klingeberg et al., 2018).

Financial markets and increasingly sophisticated technology are opening up a wide range of opportunities, accompanied by a variety of risks which can be avoided using derivatives to provide a hedge against fluctuations in interest rates, exchange rates, etc. (Bai et al., 2016; Vomačka, 2016; Ramlall, 2018). Figure 1 below shows the distribution of derivatives by product based on data of 2018 .

The majority of derivatives are interest rate derivative contracts, which account for $63,44 \%$. Foreign exchange derivatives make up 12,63\%. According to the data on derivatives provided by the Bank for International Settlements (2019), most transactions can be claimed to be entered into in U.S. dollars, though euro-, pound sterling- and Japanese yen-denominated transactions are also popular. The most popular (short-term, up to one year) transactions account for about $78 \%$ of all transactions. Commodity, credit, and equity derivative contracts comprise a small proportion of all transactions (Bank for International Settlements, 2019). 


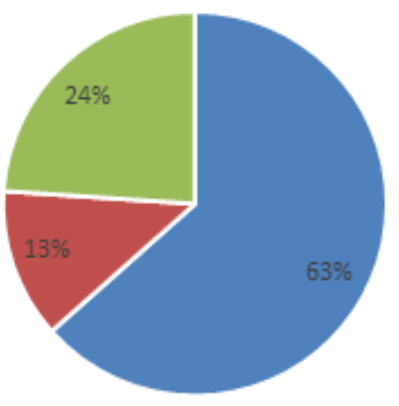

- Interest rate contracts

- Foreign exchange transactions

- Other derivative contracts

Figure 1. Distribution of derivative financial instruments in Lithuania (Bank for International Settlements, 2019; European Central Bank, 2019, Bank of Lithuania, 2019; Statistics Lithuania, 2019).

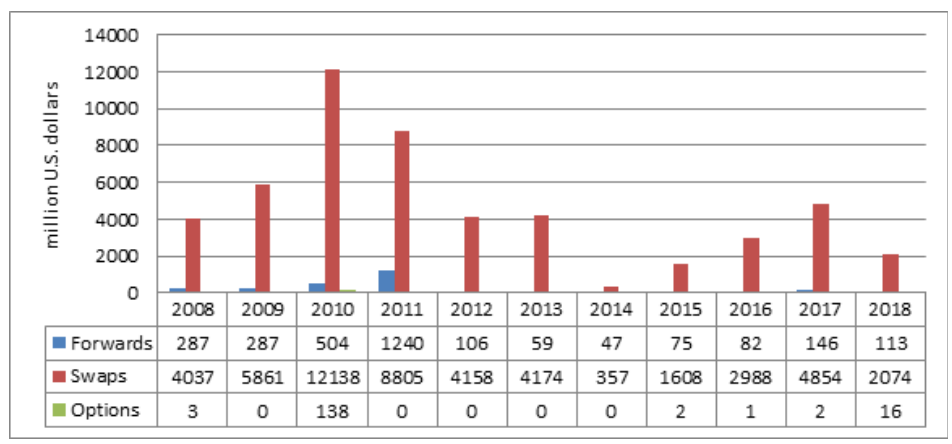

Figure 2. Foreign exchange transactions in Lithuania during 2008-2018 (Bank for International Settlements, 2019; European Central Bank, 2019; Bank of Lithuania, 2019; Statistics Lithuania, 2019). 
The foreign exchange market has become particularly popular worldwide over the last few decades, and over the last 10 years it has also grown in Lithuania (Bank of Lithuania, 2019; Statistics Lithuania, 2019). Therefore, this article provides a broader analysis of foreign exchange transactions.

From 1997 until 2018, the foreign exchange market turnover increased 1000 times (from 5 billion U.S. dollars to 5,5 trillion U.S. dollars), from 2001 until 2018 it increased $267 \%$ (from 1,5 to 3 trillion U.S. dollars), from 2010 until 2018 it increased $40 \%$ (up to 5,5 trillion U.S. dollars) (Bank for International Settlements, 2019; European Central Bank, 2019). These developments illustrate the rapid growth of popularity of derivatives and the importance of foreign exchange. This has been greatly influenced by ever-developing technologies, which has led to a greater variety of marketing tools and easier access to information. Higher price volatility and foreign trade force enterprises around the world to manage risks, since foreign exchange rates can have a significant impact on an enterprise's expenses and profits. A matter of importance is also the economic factors that keep exchange rates constantly fluctuating.

The Lithuanian exchange derivatives market and its statistics are analysed by the Bank of Lithuania (2019), which provides data on the turnover in the foreign exchange market, currency purchase and sale forwards, swaps, and options. In Figure 2 below, we can see the distribution of foreign exchange transactions in Lithuania during the period of 20082018.

In Lithuania, swaps prevail; during the period of 2008-2018, these transactions accounted for the major share, or approximately $94 \%$, of the foreign exchange derivatives market (Bank of Lithuania, 2019; Statistics Lithuania, 2019). An analysis of forwards shows that from 2008 until 2011, the volume of these transactions was growing; a total of 1 239,62 million U.S. dollars was contracted. In 2012, the total contracted amount fell to as low as 106,18 million U.S. dollars, and since then, the contracted amounts for foreign exchange forwards in Lithuania have ranged from 47,47 million U.S. dollars to 145,94 million U.S. dollars. During the period under study, forwards made up 5,44\% of transactions in the foreign exchange derivatives market. The volume of swaps in Lithuania was increasing from 2008 until 2010, later was decreasing until 2014, and then began to grow again. However, most of the currency was purchased and sold in 2010, largely influenced by the global financial crisis, which caused substantial uncertainty about economic developments, leading to transactions to avoid risks and major currency fluctuations. Until 2014, most of such transactions comprised LTL / EUR and EUR / USD swaps. The LTL / EUR currency pair accounted for $85,56 \%$ of all swaps in 2010 and for $80,15 \%$ in 2011 , but it was also the most popular currency pair in other periods as well. During 2008-2014, the USD / EUR pair averaged $15,67 \%$. Since 2015, when Lithuania became the 19th member of the euro area, the most popular FX swap pair has become USD / EUR (Bank for International Settlements, 2019; European Central Bank, 2019; Bank of Lithuania, 2019). This pair accounted for $71,4 \%$ to $85,6 \%$ of all swaps. Options are not popular in Lithuania; during the analysed period (2008-2018), their volume amounted to 0,29 $\%$ of the total foreign exchange market turnover.

To sum up the overview of the derivatives market in Lithuania, it can be observed that swaps account for the highest number of transactions, with an average of $94,26 \%$ of the total foreign exchange market turnover during the analysed period, just as it is worldwide (Xiao, Zhang \& Fu, 2016).

\section{Analysis of Dynamics of Lithuania's Macroeconomic Indicators}

According to previous research by other authors, it is observed that foreign direct investment often has a major role to play in respect of derivatives and their volume (Brigham \& Davies, 2015; Lenee \& Oki, 2017; Jermann \& Yue, 2018). However, during a certain period of time, research may also show different results, which is why the present research focuses on the situation in Lithuania.

\subsection{Gross Domestic Product (GDP)}

GDP is calculated as the value of final goods and services produced within a country over the year, including the value generated by foreign factors of production in that country but excluding investment income received from the country's citizens abroad. This indicator is measured at factor cost, adding up the value 


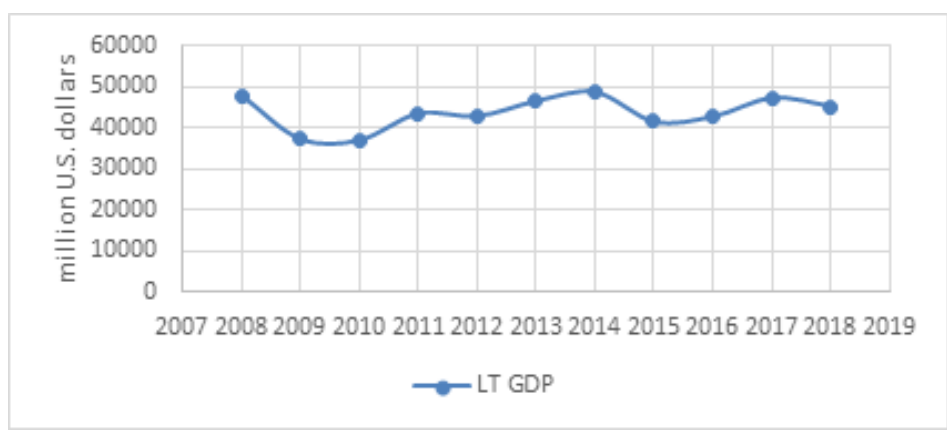

Figure 3. Lithuania's GDP during 2008-2018 (Bank for International Settlements, 2019; European Central Bank, 2019, Bank of Lithuania, 2019; Statistics Lithuania, 2019.

added by each country and firm (Ramlall, 2018). GDP is considered one of the main indicators determining the growth of the country's economy, showing the nature of development, its speed, as well as the potential and tendencies of the rise of public welfare (Campolmi \& Gnocchi, 2016; Vomačka, 2016; Barrel \& Nahhas, 2018).

An overview of Lithuania's GDP during the period of 2008-2018 (see Figure 3) shows that GDP fluctuated constantly. In 2008, it amounted to 47,85 billion U.S. dollars, later in 2010 dropped to 37,12 billion U.S. dollars but subsequently started to rise again and in 2014 reached 48,52 billion U.S. dollars (Bank of Lithuania, 2019; Statistics Lithuania, 2019). In 2011, GDP growth was driven mainly by value-added gains in the construction, manufacturing, trade, hotels and restaurants, transport, warehousing, and communications services sectors. During 2012-2018, Lithuania’s GDP continued to grow and the economic situation improved, driven by rising wages and incomes, which boosted consumption along with the increase in exports (Bank of Lithuania, 2019; Statistics Lithuania, 2019).
To sum up GDP dynamics, we can see that Lithuania's GDP fluctuated constantly. As GDP in Europe was falling/rising, so was Lithuania's GDP (Bank for International Settlements, 2019; European Central Bank, 2019).

\subsection{Foreign Direct Investment (FDI)}

A foreign direct investment (FDI) is an investment attracted to gain a lasting interest in enterprises operating in an economy other than that of the investor (Arabi \& Saei, 2010; Barrel \& Nahhas, 2018). FDI is a key element of international economic integration that creates direct, stable, and lasting links between economies of different countries, promotes the transfer of technology and expertise and can serve as an important tool for development (Ramlall, 2018; Giammanco \& Gitto, 2019). Foreign investment contributes significantly to a country's economic growth; thus its attraction is one of the main goals of the state (Liu, Wang \& Woo, 2019). It is observed that FDI is increasing in all regions (Barrel \& Nahhas, 2018). 


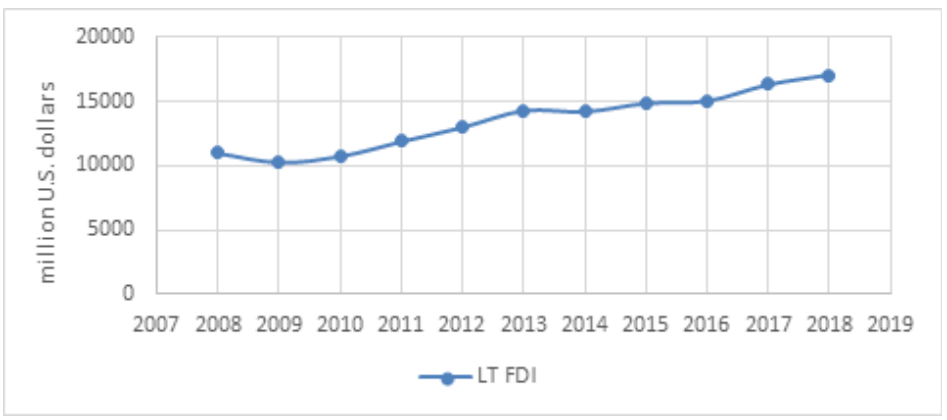

Figure 4. Foreign direct investment stocks in Lithuania during 2008-2018 (Bank for International Settlements, 2019; European Central Bank, 2019; Bank of Lithuania, 2019, Statistics Lithuania, 2019)

An analysis of foreign direct investment (FDI) in Lithuania (Figure 4) reveals that more investment is being attracted (Bank for International Settlements, 2019; European Central Bank, 2019; Bank of Lithuania, 2019, Statistics Lithuania, 2019). In 2008, FDI stocks amounted to 10997,33 million U.S. dollars and already in 2018 - 17 045,02 million U.S. dollars. As regards the distribution of FDI stocks by economic activity, investment is mainly attracted to financial and insurance activities, which during the period under analysis made up $23,05 \%$ of the total investment, manufacturing $-22,85 \%$, real estate $-12,8 \%$, wholesale and retail trade and repair of motor vehicles and motorcycles - 12,66 \%. Education, arts, entertainment and recreation activities, water supply, sewage treatment, waste management and other service activities attract the least investment in Lithuania (Bank of Lithuania, 2019, Statistics Lithuania, 2019). As regards a breakdown of FDI by country, the largest investment flows are attracted from European countries, with an average of $94,17 \%$ of the total investment over the analysed period (International Bank for Settlements, 2019; European Central Bank, 2019). A broader overview of the European countries shows that the largest investment flows are attracted from Sweden - 19,36 $\%$ of the total investment, followed by the Nether- lands - 10,25 \%, Germany - 8,94 \%, Poland - 8,62 $\%$. American investment stands at 3,23\% and Asian investment - at 2,31\% (Statistics Lithuania, 2019). Lithuania attracts substantial investment due to highly valued qualifications of its workers, its infrastructure and logistics.

\subsection{Inflation Rates}

Inflation, as a long-term increase in the general price level, has a major influence on the processes taking place in a country. As prices increase, the purchasing power of money decreases. It is argued that inflation rates can be increased by the rate of GDP growth, though higher inflation rates can lead to economic decline (Wan \& Chen, 2017). In Figure 5 below, we can see inflation rates in Lithuania during the period of 2008-2018.

The highest inflation rate in Lithuania was in 2008 and reached $10,93 \%$, mainly because of the global financial crisis (Bank for International Settlements, 2019; European Central Bank, 2019). According to the Bank of Lithuania (2019), inflation rates started to decline in 2009-2010 as food prices rose more slowly and oil prices increased less, which slowed down the annual increase in fuel prices. In 2011, inflation rates in Lithuania slightly increased, mainly because of 


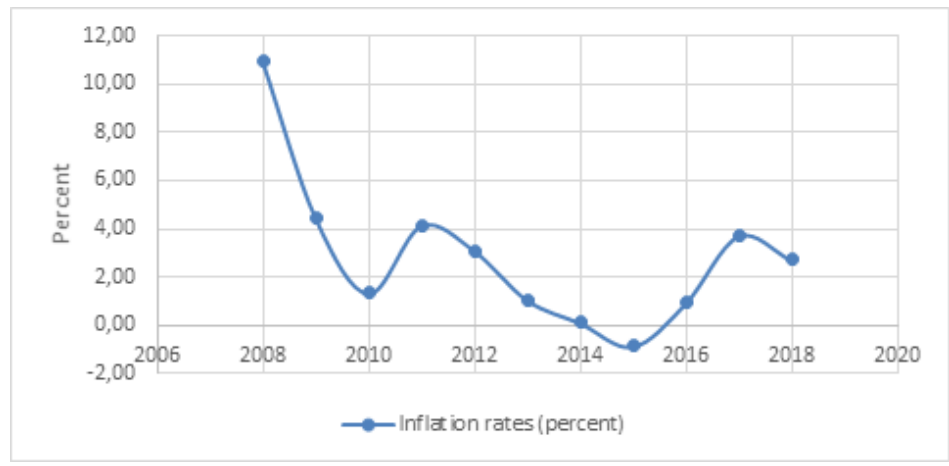

Figure 5. Inflation rates in Lithuania (Bank for International Settlements, 2019; European Central Bank, 2019; Bank of Lithuania, 2019; Statistics Lithuania, 2019)

food prices, which were dependent on global market trends; their impact on inflation rates increased, hence the impact of external factors remained very significant (Bank of Lithuania, 2019; Statistics Lithuania, 2019). Subsequently, inflation rates began to decrease due to favourable external and domestic developments, accompanied by a fall in food and fuel prices, as these price groups are related to external factors, i.e., developments in global raw materials markets. The domestic situation also improved, with changes in prices of industrial goods and market services (Bank of Lithuania, 2019). During 2011-2015, inflation rates decreased by $5,01 \%$. During 2016-2017, inflation rates picked up again, driven by changing trends in global raw materials markets, rising fuel prices and prices of some foodstuffs, especially milk and milk products, oils, and fats. However, domestic economic developments also contributed to a significant extent to inflation rates during this period, as prices for services were increasing. Wages were also growing, which led to a rise in domestic demand and prices (Bank of Lithuania, 2019; Statistics Lithuania, 2019). It can be observed that inflation rates in Lithuania mainly depend on global raw materials markets. Thus, summarising the research data it can be claimed that inflation rates in Lithuania constantly fluctuate.

\subsection{Unemployment Rate}

The rate of unemployment, as a ratio of the unemployed to the labour force expressed in percentage, is of major economic and social importance (Blažek \& Netrdova, 2012). For the economy, high unemployment means that a part of the population does not work and therefore does not contribute to the economic well-being of a country and to collection of the budget, which has a particular impact on economic growth and strengthening of the country (Campolmi \& Gnocchi, 2016). However, it becomes more complicated for a person to find a job and financial difficulties arise. Figure 6 shows Lithuania's unemployment rate during the period of 2008-2018.

In analysing the rate of unemployment in Lithuania, it can be noted that unemployment rose from 5,83\% to $17,81 \%$, driven by the economic downturn, which forced businesses to reduce their staff and capacity to remain on the market (Bank for International Settlements, 2019; European Central Bank, 2019). Thus, unemployment increased, wages fell and uncertainty about the future grew (Bank of Lithuania, 2019). In 2011, a decline in the unemployment rate was observed, mainly due to the services sector being the largest in terms of employment, in particular as regards transport and storage, administrative and 


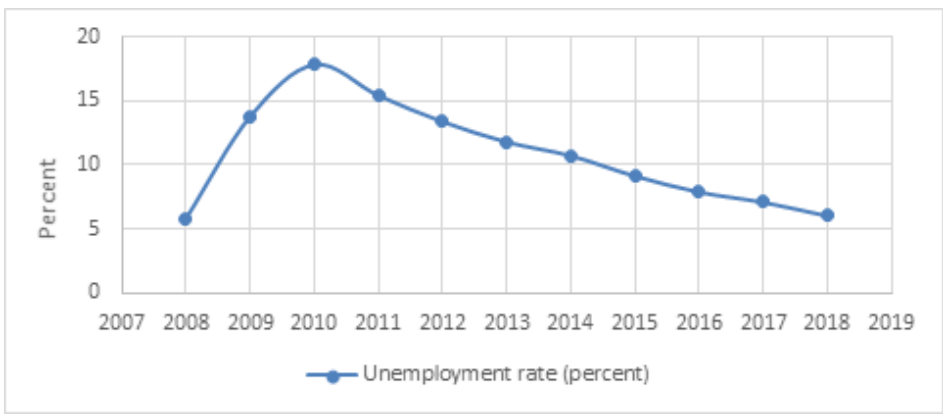

Figure 6. Lithuania's unemployment rate during 2008-2018 (Bank for International Settlements, 2019; European Central Bank, 2019; Bank of Lithuania, 2019; Statistics Lithuania, 2019).

support activities (Bank of Lithuania, 2019; Statistics Lithuania, 2019). Throughout the period under review, unemployment continued to decline and domestic demand continued to grow, which led to economic growth. During 2012-2014, employment was strongly affected by the recovery in the construction sector. In 2015, the domestic market, employment and activity rates continued to grow, leading not only to lower unemployment but also to rapid wage growth (Bank of Lithuania, 2019; Statistics Lithuania, 2019).

In 2015, slower employment growth was observed, along with labour shortages being more widely experienced and the rate of unemployment reaching 7,86 $\%$. During 2017-2018, labour shortages continued to be experienced, especially in major cities, as well as the balancing of migration flows was observed (Bank of Lithuania, 2019). Thus, from 2010 until 2018 the rate of unemployment fell from $17,81 \%$ to $6,01 \%$.

Summarising data on the unemployment rate in Lithuania, it can be stated that the unemployment rate had risen to $17,81 \%$, but then declined, and since 2013 it has fallen below the European average (Barrel \& Nahhas, 2018).

\subsection{Average Annual Earnings}

Average earnings reflect the average remuneration of those employed in an economy (Gerdesmeier, 2015). In Figure 7 below, we can see average annual earnings in Lithuania during 2008-2018 (Bank of Lithuania, 2019; Statistics Lithuania, 2019).

An overview of average annual earnings in Lithuania shows that in 2008-2010, the decline was mainly in the public sector due to the global financial crisis, which resulted in rising unemployment and decreasing wages (Bank of Lithuania, 2019; Statistics Lithuania, 2019). Later on, average earnings fluctuated slightly, and in 2011 they grew up to 9673 U.S. dollars per annum, with the largest increase in earnings observed in the construction and agricultural sectors (Bank of Lithuania, 2019; Statistics Lithuania, 2019). In 2012, average annual earnings fell slightly but later started to pick up again and in 2014 totalled 10782 U.S. dollars. The growth was mainly driven by decreasing unemployment, relatively rapid employment growth and increasing minimum wages (Bank of Lithuania, 2019; Statistics Lithuania, 2019). In 2015, earnings fell slightly, but in 2016-2018 they started to rise on account of labour shortages and government decisions: 


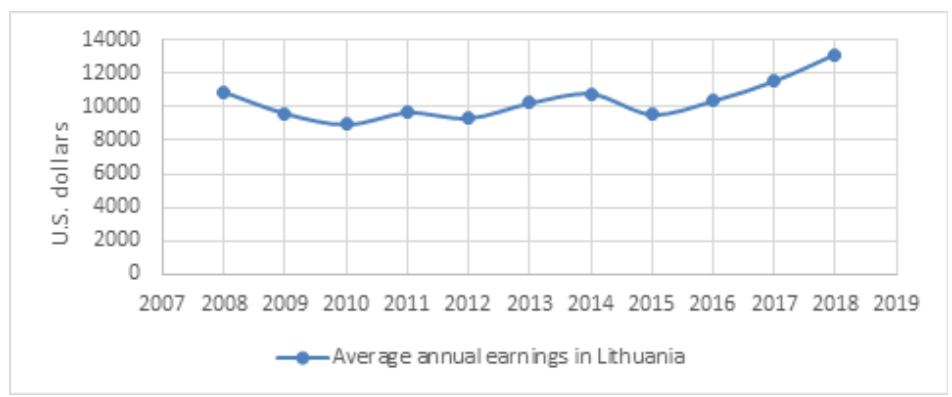

Figure 7. Average annual earnings in Lithuania (Bank of Lithuania, 2019; Statistics Lithuania, 2019).

increase of wages for public administration, education, and health workers (Bank of Lithuania, 2019; Statistics Lithuania, 2019).

Summarising data on average annual earnings, we can see that all markets display growth driven by rising commodity and service prices, raw material prices, and hence increase in minimum wages and average earnings.

\section{Estimation of the relationship be- tween derivatives and macroeconomic indicators}

The world is continuously undergoing a variety of economic processes that affect people's lives, a country's economic situation, and thus investment (Gerdesmeier, 2015; Bai et al., 2016). The purpose of this study is to estimate the relationship between derivatives and selected macroeconomic factors in Lithuania. Table 1 below shows how derivatives are affected by certain macroeconomic factors (Bekešienè, 2015).

The examination of the impact of macroeconomic factors on foreign exchange derivatives in Lithuania shows (Table 1) that the coefficient of correlation between derivatives and GDP is equal to $-0,573$. Since $r$ is equal to $-0,573$, there exists a moderate inverse relationship, which is statistically significant, as the $\mathrm{p}$-value equals 0,033 . The coefficient of correlation between the derivatives and FDI equals to $-0,625$, which implies a moderate inverse relationship. The correlation coefficient is statistically significant, since the $\mathrm{p}$-value is equal to 0,02 . The coefficient of correlation between the derivatives and inflation stands at 0,184 . Since $r$ is equal to 0,184 , there is a weak direct relationship, but the correlation coefficient is insignificant, as the p-value is 0,294 . The coefficient of correlation between the derivatives and the unemployment rate equals to 0,735 . Since $r$ is 0,735 , it is claimed that there is a strong direct relationship, which is statistically significant, because the p-value is 0,005 . The coefficient of correlation between the derivatives and average earnings equals $-0,501$. Since $r$ is equal to $-0,501$, there exists a moderate inverse relationship, which is statistically insignificant, as the p-value is equal to 0,058 .

Table 2 presents results of the examination of the relationship between derivatives and the macroeconomic factors under consideration by means of binomial regression analysis (Bekešienè, 2015). 
Table 1. Results of Correlation Analysis of Derivative Financial Instruments in Lithuania

\begin{tabular}{lccc}
\hline Correlation between $\mathbf{Y}$ and $\mathbf{X}$ & Pearson correlation coefficient & p-value & Strength of the relationship \\
\hline Derivatives and GDP & $-0,573$ & 0,033 & Moderate \\
Derivatives and FDI & $-0,625$ & 0,020 & Moderate \\
Derivatives and inflation & 0,184 & 0,294 & Weak \\
Derivatives and unemployment rate & 0,735 & 0,005 & Strong \\
Derivatives and average earnings & $-0,501$ & 0,058 & Moderate \\
\hline
\end{tabular}

Table 2. Results of the Examination of Derivatives and All Factors

\begin{tabular}{lccc}
\hline Factors & $\mathbf{R}$ & $\mathbf{R}^{\mathbf{2}}$ & Standard error \\
\hline Derivatives and GDP & 0,573 & 0,329 & 3143,805 \\
Derivatives and FDI & 0,625 & 0,390 & 2995,688 \\
Derivatives and inflation & 0,184 & 0,034 & 3770,884 \\
Derivatives and unemployment rate & 0,735 & 0,541 & 2600,358 \\
Derivatives and average earnings & 0,501 & 0,251 & 3320,513 \\
\hline
\end{tabular}

We can see from Table 2 that the coefficient of determination (R2) of GDP is equal to 0,329 , which means GDP contributes to $32,9 \%$ of variance in derivatives. The coefficient of determination (R2) of FDI is 0,39 , which explains $39 \%$ of variance in derivatives. The coefficient of determination (R2) of inflation equals to 0,034 , which indicates that $3,4 \%$ of variance in derivatives can be attributed to inflation. The coefficient of determination (R2) of the unemployment rate is equal to 0,541 , which accounts for $54.1 \%$ of variance in derivatives. The determination coefficient (R2) of average salary equals to 0,251 , which means that $25,1 \%$ of variance in derivatives is attributed to average earnings.

Binary regression analysis has allowed to identify statistically significant variable factors, which in turn serve as a basis for multiple correlation (regression) analysis. In this case, a model including GDP, FDI and the unemployment rate is constructed.

Based on Table 3, we see that the coefficient of correlation between derivatives and selected variable factors is equal to 0,769 , indicating that there is a strong direct relationship. The resulting coefficient of determination R2 stands at 0,592, which suggests that the model explains $59,2 \%$ of variance in foreign exchange derivatives.

In Table 4, we see the value of Fisher criterion, which is equal to 3,380 . Selecting the significance level $\alpha=$ 0,05 , we get that F0,05 $(3 ; 11-3-1)=4,347>3,380=\mathrm{F}$, hence we claim that the model is not suitable for forecasting. However, calculating with $\alpha=0,1$, we obtain that F0.1 $(3 ; 11-3-1)=3.453<3.609=$ F. Thus, the model is suitable for forecasting at $\alpha=0,1$.

In order to determine whether all variables in the model are statistically significant, we will look at Table 5 , where we can see coefficient estimates, standard errors of coefficients, standardised coefficients, as well as the level of multicollinearity and significance.

It can be seen from Table 5 that the level of GDP is most above the selected significance level $\alpha=0,1$, so we remove this variable and continue regression analysis to obtain a valid model. The model is constructed with two variables: FDI and the unemployment rate.

We can see from Table 6 that the coefficient of determination R2 is equal to 0,582 , which means that 58,2 $\%$ of variance in of foreign exchange derivatives can be explained by FDI and the unemployment rate. The correlation coefficient $(\mathrm{R})$ equals to 0,763 and indicates the presence of a strong direct relationship.

Table 7 shows that the value of Fisher criterion is equal to 5,563. Selecting the significance level $\alpha=0.1$, we find that F0,1 $(2 ; 11-2-1)=3,113<5,563=\mathrm{F}$, hence we claim that the model is suitable for forecasting. 
Table 3. Model Summary Including Statistically Significant Factors

Model Summary

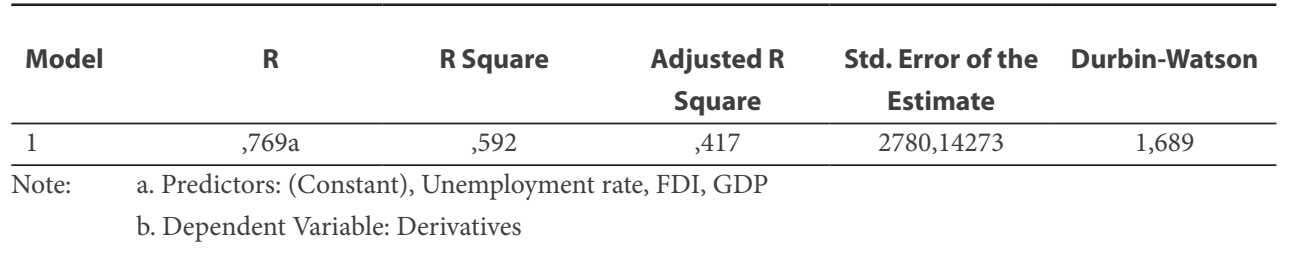

Table 4. Summary for the Analysis of Variance (ANOVA)

ANOVAa

\begin{tabular}{lcccccc}
\hline Model & & Sum of Squares & df & Mean Square & F & Sig. \\
\hline 1 & Regression & 78372035,754 & 3 & 26124011,918 & 3,380 &, $084 \mathrm{~b}$ \\
& Residual & 54104355,209 & 7 & 7729193,601 & & \\
\\
Total & 132476390,963 & 10 & & & \\
\hline
\end{tabular}

Note: a.Dependent Variable: Derivatives

b.Predictors: (Constant), Unemployment rate, FDI, GDP

Table 5. Regression Model Including Statistically Significant Factors

Coefficients $^{\mathrm{a}}$

\begin{tabular}{lcccccccc}
\hline Model & Unstandardized B & $\begin{array}{c}\text { Coefficients } \\
\text { Std. Error }\end{array}$ & $\begin{array}{c}\text { Standardized } \\
\text { Coefficients } \\
\text { Beta }\end{array}$ & $\mathbf{t}$ & $\begin{array}{c}\text { Sig. } \\
\text { Collinearity } \\
\text { Tolerance }\end{array}$ & $\begin{array}{c}\text { Statistics } \\
\text { VIF }\end{array}$ \\
\hline (Constant) & 10653,413 & 16473,147 & &, 647 &, 538 & & \\
GDP & $-123,219$ & 299,615 &,- 132 &,- 411 &, 693 &, 570 & 1,755 \\
FDI &,- 386 &, 504 &,- 243 &,- 766 &, 469 &, 580 & 1,724 \\
Unemployment & 451,408 & 327,222 &, 495 & 1,380 &, 210 &, 452 & 2,211 \\
\hline
\end{tabular}

Note: a.Dependent Variable: Derivatives

Table 6. Model Summary (After Removing One Independent Variable (Gdp), With Independent Variables: Unemployment Rate, FDI)

Model summary

\begin{tabular}{lccccc}
\hline Model & $\mathbf{R}$ & R Square & $\begin{array}{c}\text { Adjusted R } \\
\text { Square }\end{array}$ & $\begin{array}{c}\text { Std. Error of the } \\
\text { Estimate }\end{array}$ & $\begin{array}{c}\text { Durbin- } \\
\text { Watson }\end{array}$ \\
\hline 1 &, $763 \mathrm{a}$ &, 582 &, 477 & 2631,81545 & 1,502 \\
\hline Note: & $\begin{array}{l}\text { a.Predictors: (Constant), Unemployment rate, FDI } \\
\text { b.Dependent Variable: Derivatives }\end{array}$ & & & \\
& b.Den & & &
\end{tabular}


We have obtained that all $\mathrm{p}<0,1$, thus rejecting the null hypothesis and asserting that the coefficients are statistically significant at the significance level $\alpha=0,1$. It is important to check the multicollinearity of the variables analysed. VIF statistics (Table 8) show that FDI and the unemployment rate are equal to 1,684 , which is less than 4, suggesting that there are no multicollinear variables that undermine the stability of regression coefficients.

In multiple regression analysis, it is important to estimate standardised residuals (residual errors). From the normal P-P plot of standardised residuals shown in Figure 8 , we can see that residuals are distributed close enough to the linear trend line, which means that there are no significant deviations from normality.

We also see a histogram of regression standardised residuals (Figure 9), where residuals are distributed normally as they do not exceed the threshold of 3 .

Based on the Durbin-Watson coefficient calculated using Table 6, we can perform the Durbin-Watson test, which will confirm whether there is autocorrelation in residuals. For the Durbin-Watson statistic (d) presented in Figure 10, we find lower and upper bounds of the critical values. The following inequality is obtained: $0,66<1,502<1,60$. This indicates that autocorrelation of residuals is statistically insignificant.

Finally, after analysing the information presented, it is possible to construct the following multiple linear regression equation based on Table 8:

$y=-0,418 X_{2}+517,146 X_{4}+4993,135$

The resulting multiple linear regression equation has been constructed according to recent data on the factors under analysis. Based on the constructed multiple linear regression equation, it can be claimed that foreign direct investment (FDI) $\left(\mathrm{X}_{2}\right)$ and the unemployment rate $\left(\mathrm{X}_{4}\right)$ are variables, that is, the macroeconomic indicators having the greatest influence on financial derivatives. The examination of the relationship between financial derivatives and macroeconomic indicators has shown that foreign exchange derivatives in Lithuania are predominantly influenced by the unemployment rate, as this coefficient yields the largest

Table 7. Summary for the Analysis of Variance (ANOVA) (With Independent Variables: Unemployment Rate, FDI)

$$
\text { Anova }^{a}
$$

\begin{tabular}{lcccccc}
\hline Model & & Sum of Squares & df & Mean Square & F & Sig. \\
\hline 1 & Regression & 77064770,633 & 2 & 38532385,317 & 5,563 &, $031 \mathrm{~b}$ \\
& Residual & 55411620,330 & 8 & 6926452,541 & & \\
& Total & 132476390,963 & 10 & 38532385,317 & & \\
\hline
\end{tabular}

Note: a.Dependent Variable: Derivatives

b.Predictors: (Constant), Unemployment rate, FDI, GDP

Table 8. Regression Model Coefficients (After Removing One Independent Variable (GDP), with Independent Variables: Unemployment Rate, FDI)

$$
\text { Coefficients }^{\mathrm{a}}
$$

\begin{tabular}{lcccccccc}
\hline Model & Unstandardized B & $\begin{array}{c}\text { Coefficients } \\
\text { Std. Error }\end{array}$ & $\begin{array}{c}\text { Standardized } \\
\text { Coefficients } \\
\text { Beta }\end{array}$ & $\mathbf{t}$ & Sig. & $\begin{array}{c}\text { Collinearity } \\
\text { Tolerance }\end{array}$ & $\begin{array}{c}\text { Statistics } \\
\text { VIF }\end{array}$ \\
\hline (Constant) & 4993,135 & 8568,901 & &, 583 &, 576 & & \\
FDI &,- 418 &, 471 &,- 263 &,- 887 &, 082 &, 594 & 1,684 \\
Unemployment & 517,146 & 270,290 &, 568 & 1,913 &, 092 &, 594 & 1,684 \\
rate & & & & & & & & \\
Unemployment & 451,408 & 327,222 &, 495 & 1,380 &, 210 &, 452 & 2,211 \\
\hline
\end{tabular}

Note: a.Dependent Variable: Derivatives 


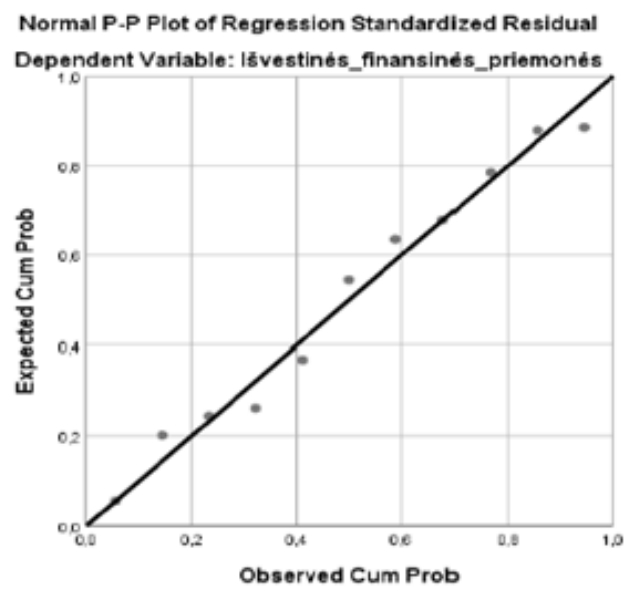

Figure 8. Normal P-P plot of regression standardised residuals.

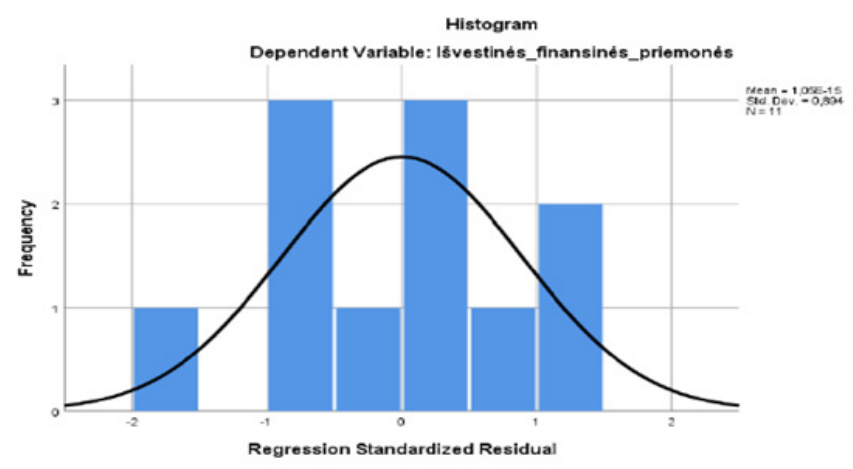

Figure 9. Histogram of regression standardised residuals. 


\begin{tabular}{|c|c|c|c|c|c|c|c|c|c|c|}
\hline \multicolumn{11}{|c|}{ Critical Values for the Durbin-Watson Statistic (d) } \\
\hline \multicolumn{11}{|c|}{ Level of Significance $\boldsymbol{\alpha}=.05$} \\
\hline \multirow{2}{*}{$\boldsymbol{n}$} & \multicolumn{2}{|c|}{$k-1$} & \multicolumn{2}{|c|}{$k-2$} & \multicolumn{2}{|c|}{$k-3$} & \multicolumn{2}{|c|}{$k-4$} & \multicolumn{2}{|c|}{$k-5$} \\
\hline & $d_{L}$ & $d_{v}$ & $d_{\mathbf{L}}$ & $\mathbf{d}_{\mathbf{v}}$ & $d_{L}$ & $\mathbf{d}_{\mathrm{v}}$ & $d_{\mathbf{L}}$ & $d_{u}$ & $d_{L}$ & $d_{u}$ \\
\hline 6 & 0.61 & 1.40 & & & & & & & & \\
\hline 7 & 0.70 & 1.36 & 0.47 & 1.90 & & & & & & \\
\hline 8 & 0.76 & 1.33 & 0.56 & 1.78 & 0.37 & 2.29 & & & & \\
\hline 9 & 0.82 & 1.32 & 0.63 & 1.70 & 0.46 & 2.13 & 0.30 & 2.59 & & \\
\hline 10 & 0.88 & 1.32 & 0.70 & 1.64 & 0.53 & 2.02 & 0.38 & 2.41 & 0.24 & 2.82 \\
\hline 11 & 0.93 & 1.32 & 0.66 & 1.60 & 0.60 & 1.93 & 0.44 & 2.28 & 0.32 & 2.65 \\
\hline 12 & 0.97 & 1.33 & 0.81 & 1.58 & 0.66 & 1.86 & 0.51 & 2.18 & 0.38 & 2.51 \\
\hline 13 & 1.01 & 1.34 & 0.86 & 1.56 & 0.72 & 1.82 & 0.57 & 2.09 & 0.45 & 2.39 \\
\hline 14 & 1.05 & 1.35 & 0.91 & 1.55 & 0.77 & 1.78 & 0.63 & 2.03 & 0.51 & 2.30 \\
\hline 15 & 1.08 & 1.36 & 0.95 & 1.54 & 0.82 & 1.75 & 0.69 & 1.97 & 0.56 & 2.21 \\
\hline
\end{tabular}

Figure 10. Values for the Durbin-Watson statistic (d).

value. Based on the formula, FDI influences the derivatives to a lesser extent. The findings of the study suggest that in order to forecast and manage the volume of derivatives transactions, it is necessary to regulate the volume of foreign direct investment, in particular the unemployment rate, taking into account social programmes in this area and their implementation.

It is likely that the use of this multiple linear regression equation could allow for the forecasting and modelling of the volume of derivatives. Similar studies are to be carried out also in the future as the changing economic situation will make it necessary to update previous findings.

\section{Conclusions}

An analysis of statistics on derivative financial instruments and macroeconomic indicators in Lithuania has shown that derivatives are becoming increasingly popular in Lithuania. Lithuania was particularly affected by the global financial crisis, during which inflation and unemployment rates rose sharply, leading to a fall in GDP, which led to an increase in derivatives risks, changes in approaches towards them and their regulation. Following the crisis, however, all these indicators started to improve, as illustrated in the graphs.
Correlation/regression analysis and multiple regression analysis between derivative financial instruments and macroeconomic indicators have revealed that derivatives in Lithuania are affected by different factors. It has been established that, according to recent data on the factors under research, foreign direct investment and the unemployment rate have the greatest impact on the derivatives in Lithuania.

In different markets, derivatives are affected by different macroeconomic factors. According to global experience, foreign direct investment (FDI) often has the largest impact on derivative financial instruments, while average earnings have the least impact. In derivatives transactions, it is important to take into account macroeconomic indicators and their forecasts, with particular reference to foreign direct investment, since it is important to estimate the effect which the economic situation may have on a transaction.

Given the research findings, it is important to timely identify the adequate relationship between derivatives and macroeconomic indicators, therefore the research should be regularly updated to more accurately model any new situation that has emerged due to changing economic conditions. 


\section{References}

Antelo, M., \& Bru, L. (2018). Option Contracts in a Vertical Industry. The Manchester Scholl, 86(4), 533-557. https://doi.org/10.1111/manc.12204

Arabi, A., \& Saei, M. (2010). Simple foreign currency option Hedge strategies. A comparison of Option contracts versus Forward contracts [Bachelor thesis, Mälardalen University College]. Digitala Vetenskapliga Arkivet. https://www.diva-portal. org/smash/record.jsf?pid=diva2\%3A327907\&ds wid $=-4290$

Araujo, G. S., \& Leao, S. (2016). OTC derivatives: Impacts of regulatory changes in the non-financial sector. Journal of Financial Stability, 25, 132-149. https://doi.org/10.1016/j.jfs.2015.11.002

Bae, S. C., Kim H. S. K., \& Kwon, T. H. (2017). Currency derivatives for hedging: New evidence on determinants, firm risk, and performance. Journal of Futures Markets, 38(4), 446-467. https://doi. org/10.1002/fut.21894

Bai, J., Philippon, T., \& Savov, A. (2016). Have financial markets become more informative? Journal of Financial Economics, 122, 625-654. https://doi. org/10.1016/j.jfineco.2016.08.005

Barrel, R., \& Nahhas, A. (2018). Economic Integration and Bilateral FDI stocks: The impacts of NAFTA and the EU [CFM discussion paper series no. CFM-DP2018-14]. The Department of Economics and Finance, Brunel University. http://eprints. lse.ac.uk/90372/

Bartram, S. M., Brown, G. B., \& Fehle, F. (2009). International evidence on financial derivatives usage. Financial Management, 38(1), 185-206. https:// doi.org/10.1111/j.1755-053X.2009.01033.x

Bejol, P., \& Livingstone, N. (2018). Revisiting currency swaps: Hedging real estate investments in global city markets. Journal of Property Investment \& Finance, 36(2), 199-219. https://doi.org/10.1108/ JPIF-04-2017-0026

Bekešienè, S. (2015). Duomenu analizès SPSS pagrindai [Basic principles of SPSS data analysis]. Vilnius. https://www.spssanalize.lt/wp-content/ uploads/2019/01/knyga-duomenu-analizes-spss-pagrindai-internetui.pdf

Bezzina, F. H., \& Grima, S. (2012). Exploring factors affecting the proper use of derivatives. Managerial Finance, 38(4), 414-417. https://doi. org/10.1108/03074351211207554

Bingham, N. H., \& Kiesel, R. (2013). Risk-neutral valuation: Pricing and hedging of financial derivatives. Springer Science \& Business Media.
Blažek, J., \& Netrdová, P. (2012). Regional unemployment impacts of the global financial crisis in the new member states of the EU in Central and Eastern Europe. European Urban and Regional Studies, 19(1), 42-61. https://doi. org/10.1177/0969776411428650

Brigham, E., \& Daves, P. (2015). Intermediate Financial Management (12th ed.). Cengage Learning.

Burns, Ch., \& Tobin, P. (2016). The impact of the economic crisis on European Union environmental policy. JCMS: Journal of Common Market Studies, 54(6), 1485-1494. https://doi.org/10.1111/ jcms.12396

Butt, A. A., Nazir, M. S., Arshad, H. \& Shahzad, A. (2018). Corporate derivatives and ownership concentration: Empirical evidence of non-financial firms listed on Pakistan stock exchange. Journal of Risk Financial Management, 11(3), 33. doi:10.3390/ jrfm11030033

Campolmi, A., \& Gnocchi, S. (2016). Labor market participation, unemployment and monetary policy. Journal of Monetary Economics, 79, 17-29. https://doi.org/10.1016/j.jmoneco.2016.03.001

Carneiro, R. M., Rossi, P., Mello G. S., \& ChiliatooLeite M. V. (2015). The fourth dimension: Derivatives and financial dominance. Review of Radical Political Economics, 47(4), 641-662. https://doi. org/10.1177/0486613415574268

David, G. (2009). Did recent experience of a financial crisis help in coping with the current financial turmoil? The case of the Nordic countries. JCMS: Journal of Common Market Studies, 47(5), 997-1015. https://doi.org/10.1111/j.1468-5965.2009.02032.x

ESMA (European Securities and Markets Authority), 2018. EU Derivatives Markets. https://www.esma. europa.eu/sites/default/files/library/esma50-165639_esma-rae_asr-derivatives_2018.pdf

Europos Centrinis Bankas [European Central Bank]. 2019 metų ataskaita [Annual Report 2019]. https://www.ecb.europa.eu/pub/annual/html/ ar2019 c199d3633e.en.html

Faure, AP. (2015). Derivative Market: An Introduction. Bookbon.com

Foster, J. B., \& Magdoff, F. (2009). The great financial crisis: Causes and consequences. NYU Press.

Gerdesmeier, D. (2015). Fundamentals of monetary policy in the euro area: Concepts - markets - institutions. 3 rd edition. Bookbon.com

Giammanco, M. D., \& Gitto, L. (2019). Healt expenditure and FDI in Europe. Economic Analysis and Policy, 62, 255- 267. https://doi.org/10.1016/j. eap.2019.04.001 
Inekwe, J. (2018). Financial crises and the extreme bounds of predictors. Empirical Economics, 55(4), 2047-2067. https://doi.10.1007/s00181-017-1352-0.

Jermann, U. J., \& Yue, V. Z. (2018). Interest rate swaps and corporate default. Journal of Economic Dynamics and Control, 88, 104-120. https://doi. org/10.1016/j.jedc.2018.01.022

Kazi, I. A., Wagan, H., \& Akbar, F. (2013). The changing international transmission of U.S. monetary policy shocks: Is there evidence of contagion effect on OECD countries. Economic Modelling, 30, 90-116. https://doi.org/10.1016/j.econmod.2012.07.020

Klingeberg, J. G., Hang, M. \& Rathgeber, A. W. (2018). What drives financial hedging? A meta-regression analysis of corporate hedging determinants. International Review of Financial Analysis, 61, 203-221. https://doi 10.1016/j.irfa.2018.11.006.

Kosowski, R. L., \& Neftci, S. (2015). Principles of financial engineering. Academic Press.

Lel, U. (2014). Currency hedging and corporate governance: A cross-country analysis, Journal of Corporate Finance, 18(2), 221-225. https://doi. org/10.1016/j.jcorpfin.2011.12.002

Lenee, T. L. \& Oki, J. (2017). Financial derivatives and firm performance: empirical evidence from financial and non-financial firms. British Journal of Economics, Management \& Trade, 16(4) 1-36. https:// doi.org/10.9734/BJEMT/2017/30106

Lietuvos bankas [Bank of Lithuania]. (2019). Lietuvos ekonomikos apžvalga [Lithuanian Economic Review]. https://www.lb.lt/uploads/ publications/docs/21756_d778713ca234ccc09dc70e7312b44d89.pdf

Lietuvos bankas [Bank of Lithuania]. (2019). $2016 \mathrm{~m}$. Lietuvos valiutu ir išvestiniu finansiniu priemoniu rinku apžvalga [Lithuania survey of foreign exchange and derivatives market activity in 2016]. https://www.lb.lt/lt/naujienos/2016-m-lietuvosvaliutu-ir-isvestiniu-finansiniu-priemoniu-rinkuapzvalga

Lietuvos bankas [Bank of Lithuania]. (2019). Valiuty rinkos statistika [Foreign exchange market]. https:// www.lb.lt/int/htm.aspx

Lietuvos respublikos statistikos departamentas [Lithuanian Department of Statistics]. (2019). Tiesiogines užsienio investicijos [Foreign direct investment]. https://osp.stat.gov.lt/statistiniu-rodikliuanalize? theme $=$ all $\# /$

Martinkute-Kauliene, R. (2014). Risk Factors in derivatives markets. Entrepreneurial Business and Economics Review, 2(4). https://doi.org/10.15678/ EBER.2014.020405
Mayordomo, S., Rodriguez-Moreno, M. \& Pena, J. I. (2014). Derivatives holdings and systemic risk in the U.S. banking sector. Journal of Banking and Finance, (45), 84-104. https://doi.org/10.1016/j. jbankfin.2014.03.037

Obstfeld, M., \& Rogoff, K. S. (2009). Global Imbalances and the Financial Crisis: Products of Common Causes (CEPR discussion paper no. DP7606). SSRN Electronic Journal. https://ssrn.com/abstract $=1533211$.

Ramlall, I. (2018). Derivatives and financial stability. In I. Ramlall (Ed.), Economic areas under financial stability. Emerald Publishing Limited. https:/doi. org/10.1108/978-1-78756-841-920181004

Shibli, M. (2012). Dynamics and controllability of financial derivatives: Towards stabilization the global financial systems crisis. Journal of Mathematical Finance, 2, 54-65. http://dx.doi. org/10.4236/jmf.2012.21007

Tarptautinių atsiskaitymų bankas [Bank for International Settlements]. 2019. Išvestinių finansinių priemonių statistika [Derivatives statistics]. https://www.bis.org/statistics/about_derivatives_ stats.htm?m=6\%7C32\%7C639

Vomačka, O. (2016). Currency risk management in selected exporting company [Master thesis, Vysoká škola ekonomická v Praze]. CVUT Dspace. https://dspace.cvut.cz/bitstream/ handle/10467/64493/MU-DP-2016-Vomacka-Ondrej-Vomacka_Ondrej_DP_01_2016. pdf? sequence $=-1$ \&isAllowed $=y$

Wan, N., \& Chen, X. (2019). The role of put option contracts in supply chain management under inflation. International Transactions in Operational Research, 26(4), 1451-1474. https:/doi. org/10.1111/itor.12372

Xiao, C. Zhang, Y., \& Fu, Z. (2016). Valuing interest rate swap contracts in uncertain financial market. Sustainability, 8(11), 1186. https://www.mdpi. com/2071-1050/8/11/1186/htm 